\title{
Financial Sustainability Ratio and Aspects That Affect It
}

\author{
Andi Rustam ${ }^{*}$ and Muhammad Adil ${ }^{2}$ \\ ${ }^{1,2}$ Universitas Muhammadiyah Makassar, Sulawesi Selatan, Indonesia \\ Email Address: \\ andirust99@gmail.com $^{1 *}{ }^{*}$ muh.adil@unismuh.ac.id ${ }^{2}$
}

\begin{abstract}
This study aims to examine the effect of Return On Assets (ROA), Capital Adequacy Ratio (CAR), Company Size, Operating Expenses Operating Income (OEOI), Loan To Deposit Ratio (LDR) affect the Financial Sustainability Ratio. The population in this study is the financial report data of Islamic Commercial Banks on Islamic banking statistics from January 2018 to December 2020. Sampling was done by purposive sampling method with the criteria; Islamic Commercial Banks are not in a problematic condition, or the BUS can generate profits in carrying out its operations and has been published in the Financial Services Authority (OJK). Secondary data was collected through the Indonesia Stock Exchange website and analyzed using Multiple Regression Analysis with the Ordinary Least Square model using the Eviews Version 12 software. The results found that ROA had no significant effect on the Financial Sustainability Ratio. CAR, Company Size, and LDR have a positive and significant impact on the Financial Sustainability Ratio. In contrast, OEOI was found to have a negative and significant effect on the Financial Sustainability Ratio.
\end{abstract}

Keywords: ROA, CAR, Firm Size, OEOI, LDR, Financial Sustainability Ratio.

\begin{abstract}
Abstrak: Penelitian ini bertujuan untuk menguji pengaruh Return On Asset (ROA), Capital Adequacy Ratio (CAR), Ukuran Perusahaan, Operating Expenses Operating Income (OEOI), Loan To Deposit Ratio (LDR) berpengaruh terhadap Financial Sustainability Ratio. Populasi dalam penelitian ini adalah data laporan keuangan Bank Umum Syariah pada statistic perbankan Syariah pada januari 2018-desember 2020. Pengambilan sampel dilakukan dengan metode purposive sampling dengan kriteria; Bank Umum Syariah tidak dalam kondisi bermasalah atau BUS tersebut mampu menghasilkan laba dalam menjalankan operasinya dan telah dipublikasikan di Otoritas Jasa Keuangan (OJK). Data sekunder dikumpulkan melalui website Bursa Efek Indonesia dan dianalisis menggunakan Analisis Regresi Berganda dengan model Ordinary Least Square menggunakan bantuan software Eviews Versi 12. Hasil penelitian menemukan bahwa Return On Asset (ROA) berpengaruh tidak signifikan terhadap Financial Sustainability Ratio, Sedangkan Capital Adequacy Ratio (CAR), Ukuran Perusahaan dan Loan To Deposit Ratio (LDR) berpengaruh positif dan signifikan terhadap Financial Sustainability Ratio. Lain halnya dengan Operating Expenses Operating Income (OEOI) ditemukan berpengaruh negative dan signifikan terhadap Financial Sustainability Ratio
\end{abstract}

Kata Kunci: ROA, CAR, Company Size, OEOI, LDR, Financial Sustainability Ratio. 


\section{INTRODUCTION}

Banks have a strategic role in the economy of a country. As an intermediary institution, banks play a role in mobilizing public funds used to finance investment activities and provide service facilities in payment traffic. In addition to carrying out these two plans, banks also function as a medium in transmitting monetary policy (Government) to the public.

Over the past decade, Indonesia has financed the launch of an Islamic financial system to accommodate Indonesians, the majority of whom are Muslims. The Islamic economic system in Indonesia has been extended to capital markets, insurance, mortgages, savings and lending institutions, banks, and others (Ismanto and Laksono, 2020). It enriches the Islamic system over the conventional system used to compare performance and prospects. The government has taken strategic steps to develop Islamic banking by granting licenses to conventional commercial banks to open branches. The existence of Islamic banks has given a new breath to the business world in this country, especially the banking world. Although still relatively new in the banking world, Islamic banks can advance and develop in tough competition (Mustari et al., 2020). This competition will be tougher between conventional banks and Islamic banks. Data released by the Financial Services Authority (OJK) stated that the market share of Islamic banking in 2020 is only around $6.51 \%$, with total national assets reaching Rp.608.09 trillion consisting of 14 Sharia Commercial Banks, 20 Sharia Business Units, and 163 Islamic People's Financing Bank. (OJK, 2020).

As a financial institutions, banks need to maintain their performance to operate optimally. One of the factors that banks must consider to survive is the bank's financial performance. One of the primary sources of indicators used as the basis for the assessment is the financial report of the bank concerned (Putri et al., 2018). Based on the financial statements of banks, several financial ratios can be calculated that can be used to predict the level of profit, predict the future, and anticipate conditions in the future. The company's financial condition is an essential factor that becomes a benchmark to determine the extent to which the company can maintain smooth operations so that it is not disrupted (Raranta et al., 2021). Financial performance data in the form of financial ratios is a measure to assess the development of banking from a financial perspective. The financial performance of Islamic banks can also be assessed through various variables taken from the financial statements of Islamic banks (Syakhrun et al., 2019).

The main reason for conducting a financial ratio analysis in a company is that the financial statements contain important information about the company's condition and prospects in the future (sustainability). In addition, financial ratio analysis can be used in any analytical model and predict future events, including the phenomenon of bankruptcy of an entity (Ahmad et al., 2018; Diana et al., 2021). Assessment of the performance and growth of a bank can use financial ratios. It can be seen that the financial ratio of financial sustainability is a determining ratio. It is because of sustainability and the level of banking growth in the long term (Wijayanti, 2016). The condition of banking financial performance, especially the Financial Sustainability Ratio (FSR) aspect, is essential to assess a company's sustainability in the future. One of the stakeholders interested in knowing financial institutions' performance are investors because the better the financial institution's performance, the greater the security guarantee for the funds invested (Priyadi, 2018). 
The need for FSR is measured using a compatible measuring instrument. MSI is able to become one of the measuring tools that support the implementation of FSR for the better. more can beneficial to the community through BUS in Indonesia. So that the BUS in Indonesia able to produce FSR every year. The results of the evaluation are used in correct any errors and mistakes that may occur in the FSR calculation in the bus. In the future, BUS will be able to compete with conventional banks in terms of quality, quantity, performance and others. Both domestically and abroad. Usefulness Sharia will feel much better than before.

These focal points consists of three things, first, the amount of revenue or the level of debt, the budget balance, and the percentage increase in income each year. Achievement of own rate of return is the goal of banks in making large profits by collaborating the three focuses above. So it can be said that a bank will have operational activities that are effective and efficient if the bank is able to maintain the quality of its performance continuously and sustainably by considering and reduce the risks that may arise in the process.

Financial sustainability so that you can said to have a good value if the FSR value is more than $100 \%$. This can be interpreted by saying that the total cost must be less than the total income earned by the bank. It can also be interpreted by the magnitude of the FSR value obtained through the total financial income is inversely proportional to the total financial burden listed on the income statement.

Return On Assets (ROA) influences the financial Sustainability Ratio (FSR). ROA is used to measure a bank's ability to earn a return on its assets. Harianto, (2017) argues that if the ROA value at the bank increases, the better the bank's ability to obtain a profit level will be. It means that a high ROA value provides information that the bank has good performance in generating profits and asset management (Arsyad et al., 2021).

The Financial Sustainability Ratio (FSR) is also influenced by the Capital Adequacy Ratio (CAR). CAR can assess bank performance by measuring the adequacy of capital owned by banks that contain risks. The higher this ratio, the better the bank's ability to measure the bank's capital adequacy to support risky assets, such as loans (Prasetyo \& Darmayanti, 2015). So the higher the CAR ratio, the better the bank's growth rate.

The firm size also affects the Financial Sustainability Ratio (FSR) because the company's size can affect economic activities and is closely related to banking activities. In measuring the area of a company/bank using the total assets that exist in the bank, the larger the company's size, the wider the information that can be obtained, and the information costs of large companies tend to be lower (Mulazid, 2017). So it is essential to know the size of a company as a benchmark for society in making decisions. The more people believe in the company, the better the performance and sustainability of the company in the future (Ratih and Damayanthi, 2016).

Operating Expenses Operating Income (OEOI) also affects the Financial sustainability ratio. Any increase in operating costs will result in reduced profit before tax, which will reduce the bank's profit or profitability. Bank Indonesia sets the best figure for the Operating Expenses Operating Income (OEOI) ratio below 90\% because if the Operating Expenses Operating Income (OEOI) ratio exceeds $90 \%$ to close to $100 \%$, the bank can be categorized as inefficient in carrying out its operations (Astuti et al. al., 2022). The higher the Operating Expenses Operating Income (OEOI) ratio in a bank, the lower the bank's ability to measure the level of efficiency and ability to carry out its operational activities (Hartanto et al., 2020). 
The Loan to Deposit Ratio (LDR) can be used to measure a bank's ability to repay customer withdrawals from liquidity sources (Zebua, 2014). The higher the LDR value, the lower the bank's financial sustainability ratio (Armereo, 2015). A high Loan to Deposit Ratio means the lower the liquidity capacity of the bank concerned, causing the bank's financial sustainability ratio to be low and the bank's performance getting worst (Aprilliadi, 2020). It is essential to know the LDR level to see bank sustainability.

\section{THEORITICAL REVIEW}

The basis for the need to disclose financial statements by management to shareholders/investors is explained in agency theory. According to (Jensen and Meckling, 1976), agency relationship occurs when one or more individuals called principals work with other individuals or organizations called agents. The principal will provide facilities and delegate decision-making policies to agents. Agents (company management) must provide periodic reports to the principal (shareholders) about the business they run. The principal will assess the performance of his agent through the financial statements submitted to him. Conflicts between managers (agents) and stakeholders (principals) cause agency problems. Managers' behavior is not always aimed at stakeholders' interests (principals). However, sometimes managers behave in the managers' interests without paying attention to the impact on stakeholders (principals). Imbalance of information or what is called information asymmetry conditions that spur agency conflicts due to differences in information knowledge from the manager (agent) and stakeholders (principal) so that managers can manipulate financial statement information without the stakeholders (principals) knowing the actual truth (Wicaksono and Hasthoro, 2014). Viewed from the perspective of agency theory, shareholders have more attention to the company's sustainability. Agency theory assesses the importance of incentives given to managers so that managers can be responsible for the interests of shareholders in the long term. The board has a responsibility to ensure managers' performance in increasing the value of company sustainability, which states that managers have a responsibility to act in the interests of shareholders who have long-term prospects to the company (Puspitasari and Ernawati, 2010). In this study, Financial Sustainability Ratio is influenced by Return On Assets (ROA), Capital Adequacy Ratio (CAR), Company Size, Operating Expenses, Operating Income (OEOI), Loan To Deposit Ratio (LDR).

Signal theory explains why companies urge external parties to provide financial statement information. The company urges to provide information because information asymmetry exists between the company and outside parties. After all, the company (manager) knows more about the company and its prospects than outside parties (investors, creditors). Lack of information to outsiders about the company causes them to protect themselves by charging a low price for the company. Companies can increase firm value by reducing information asymmetry (Rahayu and Cahyati, 2015). One way to reduce information asymmetry is to provide signals to outsiders, one of which is reliable financial information, reducing uncertainty about the company's prospects. Signal theory suggests how a company should signal users of financial and non-financial statements (Kurniawan and Suwarti, 2017). This signal is in the form of information about what management has done to realize the owners, namely maximizing their profits. Signals can be in promotions or other information stating that the company is better than other companies. 
Financial Sustainability Ratio disclosures can be used by management to show shareholders or investors as a signal in the form of good news given by management to the public that the company has good prospects in the future and ensures sustainable development. Return on Assets (ROA) measures the ratio to profit. The higher the percentage obtained in calculating this ratio, the better the financial condition (Shakhrun et al., 2019). The acquisition of Return on Assets influences the company's economic sustainability, commonly called the Financial Sustainability Ratio, which is seen from the number of company profits in the financial statements. Increasing profits will improve and stabilize the company's finances, where a stable financial condition will affect the smooth operation of operations because of the ability to handle financing properly. In other words, showing the company's ability to follow up on operational activities will be better and extend the company's life cycle.

Return on Assets (ROA) to Financial Sustainability Ratio (FSR) is positive, meaning that the higher the Return on Assets (ROA), the better the Financial Sustainability Ratio (FSR) (Sarwono and Sunarko, 2016). The greater the Return On Assets (ROA) of a bank, the greater the level of profit achieved by the bank and the better the bank's position in terms of the use of its assets so that the bank can continue to be a going concern is in higher. The results of the study (Rianasari and Pangestuti, 2016; Miranti, 2018; Saputri, 2019) found that Return On Assets (ROA) had a positive and significant effect on the Financial Sustainability Ratio (FSR). Different results were found by (Yuliawati et al., 2020) found that ROA had no considerable impact on Financial Sustainability Ratio (FSR).

H1: Return on Assets has a positive and significant effect on the Financial Sustainability Ratio (FSR).

Capital Adequacy Ratio (CAR) is a bank performance ratio to measure the adequacy of capital owned by a bank in supporting assets that contain risk. The relationship between the capital adequacy ratio and the financial sustainability ratio of Islamic commercial banks is that the lower the bank's capital means the bank's condition is experiencing problems. It can be interpreted that the bank has not been able to regulate financial performance properly to become an obstacle to bank sustainability (Basse and Mulazid, 2017). The results of the calculation of the CAR ratio will show the adequacy of capital owned by the bank. The bank's ability to regulate capital adequacy becomes an assessment of the bank's health. The increase in the gain from the calculation of this ratio shows the power of banks to manage and regulate capital adequacy to support assets that contain risks. Increased ability to regulate capital adequacy will help improve bank growth because it has sufficient costs to grow (Putri and Dana, 2018). Improved bank development will increase opportunities for additional capital through profits. Increasing capital followed by better management capabilities will affect the bank's financial ability to meet operational needs and other costs quickly. The bank will be guaranteed to maintain its safe position, measured in financial sustainability. Under these circumstances, the predetermined targets can achieve the Financial Sustainability Ratio. The study results (Saputri, 2019) found that the Capital Adequacy Ratio (CAR) had a positive and significant effect on the Financial Sustainability Ratio. It means that the higher the Capital Adequacy Ratio (CAR), the better the Financial Sustainability Ratio (FSR) of the bank concerned. Different research results are shown by 
research from (Larasati et al., 2019), which shows that the Capital Adequacy Ratio (CAR) has no significant effect on the Financial Sustainability Ratio.

H2: Capital Adequacy Ratio (CAR) has a positive and significant effect on Financial Sustainability Ratio (FSR).

Company size can be measured from the assets owned by the company. Assets are economic resources that are expected to provide business benefits in the future. Large companies generally have a large number of assets as well. Company size is an indicator that investors can use as one of the variables in determining investment decisions. It will affect the proportion disbursed by banks because banks maintain liquidity and increase bank profits (Hermuningsih, 2012). However, banks classified as significant will quickly get third-party funds from customers through savings, deposits, customer investments, and other bank businesses. Many third-party funds make banks have to increase the distribution of funds in the form of a credit to maintain their liquidity. High disbursement of funds makes banks face credit risk if customers cannot repay their loans. One of the possible risks is indicated by the NPL value of the bank. So it can be concluded that an increase in NPL will accompany the increase in total assets, and the risk of bad loans also increases. It will reduce the potential for bank sustainability due to bank risk. So that size has a negative and significant effect on FSR. The study results (Saputri, 2019) found that company size positively and significantly affected the Financial Sustainability Ratio.

H3: Company size has a positive and significant effect on the Financial Sustainability Ratio (FSR).

The efficiency level ratio (BOPO) has a negative effect on the Financial Sustainability Ratio (FSR), meaning that the lower the efficiency level ratio (BOPO), the better the Financial Sustainability Ratio (FSR) of a bank. In other words, banks can use their production factors optimally with good and appropriate management to increase their ability to be a going concern (Nuryanto et al., 2020). The increase in BOPO between this year and the previous year shows that the bank's efficiency and ability in carrying out its operations are getting worse, so the possibility of the bank being in a problematic condition is getting bigger. The decrease in BOPO indicates that the bank's more efficient in carrying out its business activities, the more profit the bank can achieve. The efficiency of a job is essential so that the business that is run can develop continuously. The efficiency in question includes time and cost-efficiency. Companies must make efficient in their work so that less effective costs can be reduced (Pristianingrum, 2017). In other words, companies must use costs appropriately in running their business so that the costs incurred do not swell. The results of the research by (Yuliawati et al., 2020) found that Operating Expenses Operating Income (OEOI) had a negative and significant effect on the Financial Sustainability Ratio. However, the results (Saputri, 2019) and (Abbas et al., 2020) found that Operating Expenses Operating Income (OEOI) did not affect the Financial Sustainability Ratio.

H4: Operating Expenses Operating Income (OEOI) has a negative and significant effect on the Financial Sustainability Ratio (FSR). 
The Loan to Deposit Ratio (LDR) is used to measure how much the bank's ability to meet the credit request submitted without happening (Santoso et al., 2017). This ratio is used to assess a bank's liquidity by dividing the amount of credit extended by the bank to third-party funds. Edo \& Wiagustini, (2014) suggest that the Loan to Deposit Ratio (LDR) is a measure to assess how far the bank can repay the withdrawal of funds made by depositors by relying on loans provided as a source of liquidity. If the bank can channel all the funds raised, it will benefit the bank, but this is related to the risk of the owner of the funds withdrawing the funds at any time. On the other hand, if the bank does not channel its funds, it will also be exposed to risk because of the loss of opportunity to profit. In economic conditions that are considered unfavorable, for example, the real sector is still not recovering, banks tend to extend credit to avoid high credit risk (Risky 2004; Almilia et al. 2009). The results of the study (Santoso et al., 2017) and (Sahetapy, 2019) found that the Loan to Deposit Ratio (LDR) had a significant effect on the Financial Sustainability Ratio (FSR).

H5: Loan to Deposit Ratio (LDR) has a positive effect on Financial Sustainability Ratio (FSR).

\section{METHODS}

This research is explanatory research that aims to test a theory or hypothesis to strengthen or reject the existing research theory or hypothesis. This study also examines the relationship or relationship between variables. The approach in research is quantitative because the analysis uses economic statistical tools that will test theories and look for generalizations that have predictive value (Rianse and Abdi, 2012). The population in this study is the financial report data of Islamic Commercial Banks on Islamic banking statistics in January 2018-December 2020. Sampling was carried out by purposive sampling method with criteria; Islamic Commercial Banks are not in a problematic condition, or the BUS can generate profits in carrying out its operations and has been published in the Financial Services Authority (OJK). This panel data combines time-series and cross-section data, where the time series collects observations within a specific period. While the cross-section is data collected within a certain period from the sample through the website www.idx.co.id and analyzed using the multiple linear regression analysis methods with the Ordinary Least Square model using the Eviews Version 12 software. 


\section{RESULTS}

The results of data normality using the regular probability plot graph found that the data in this study were normal and could be used.

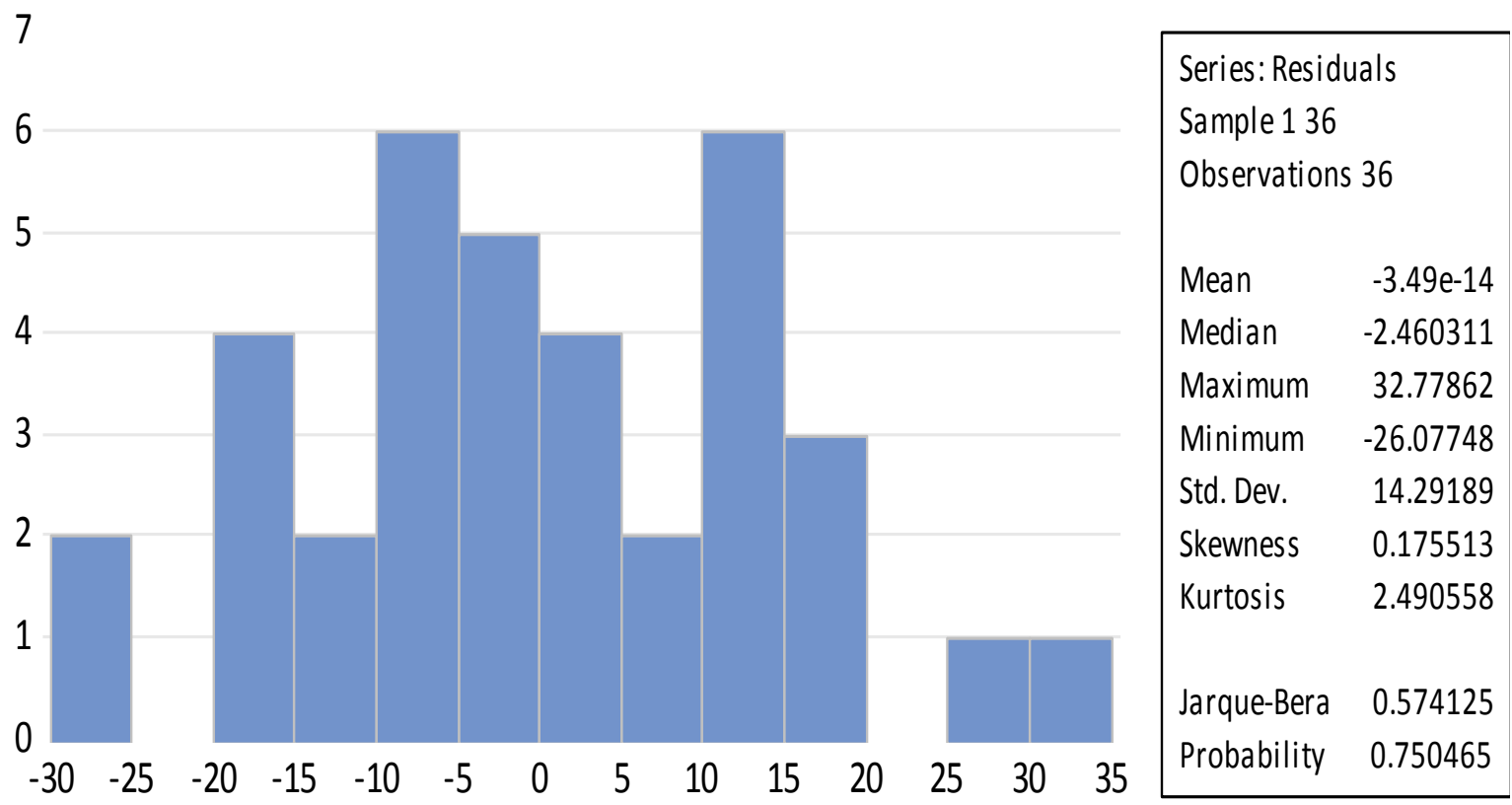

Figure 1. Normality Test Results

Source : Output Eviews V.12 (2021)

Figure 1 shows the Jarque-Bera value of 0.574125 and a significance of 0.750465 or $75.04 \%>5 \%$ significance level, meaning that the research variables are normally distributed.

Table 1. Descriptive Statistics

\begin{tabular}{llc}
\hline No & Auxiliary & Centered VIF \\
\hline 1 & Return On Asset (ROA) & 7,380 \\
2 & Capital Adequacy Ratio (CAR) & 1,208 \\
3 & Company Size & 1,705 \\
4 & Operating Expenses Operating Income (OEOI) & 5,424 \\
4 & Loan To Deposit Ratio (LDR) & 5,238 \\
\hline
\end{tabular}

Source : Output Eviews V.12 (2021)

Based on table 1, the coefficient value between the variables of the Centered VIF value is less than 10 . It can be stated that there is no multicollinearity problem in the prediction model.

Table 2. Autocorrelation Test Results

$\begin{array}{llll}\text { R-Squared } & 0.536472 & \text { Mean dependent var } & 93.43639 \\ \text { Adjusted R-Squared } & 0.459218 & \text { S.D dependent var } & 20.99190 \\ \text { S.E of Regression } & 15.43701 & \text { Akaike info criterion } & 8.462424 \\ \text { Sum squared resid } & 7149.035 & \text { Schwarz criterion } & 8.726344\end{array}$




$\begin{array}{lrlr}\text { Log likelihood } & -146.3236 & \text { Hannan-Quinn criter } & 8.554539 \\ \text { F-Statistic } & 6.944207 & \text { Durbin-Watson stat } & 0.854970 \\ \text { Prob(F-statistic) } & 0.000205 & \end{array}$

Source : Output Eviews V.12 (2021)

The results of the autocorrelation test shown in table 2 can be seen from the DurbinWatson Stat value, which is 0.854970. This value is the Durbin Watson (DW) value which is between -2 and +2 , so it can be concluded that there is no autocorrelation symptom. Then, the heteroscedasticity test is carried out to see whether a disturbance appears in the regression function. It can be done using the Harvey test.

Table 3. Heteroskedasticity Test Harvey Results

\begin{tabular}{llll}
\hline F-statistic & 0.681013 & Prob. F(5,30) & 0.6413 \\
Obs *R-squared & 3.669573 & Prob. Chi-Square (5) & 0.5979 \\
Scalled explained SS & 2.186055 & Prob. Chi-Square (5) & 0.8228 \\
\hline
\end{tabular}

Source : Data processed (PLS, 2020).

Based on table 3, the value of Prob. From F-count is equal to 0.681013 and Prob. ChiSquare count 0.6413 from all tests is greater than the $5 \%$ significance value. Then there is no heteroscedasticity in the equation model. The results of the f-count test of 6.944 and the probability value of f-statistics are $0.000<0.05$, then ROA, CAR, Company Size, OEOI, and LDR simultaneously have a significant influence on the Financial Sustainability Ratio in Islamic banking listed on the Indonesia Stock Exchange (IDX) period 2018-2020.

Table 4. Simultaneous Test (f test)

\begin{tabular}{lrll}
\hline R-Squared & 0.536472 & Mean dependent var & 93.43639 \\
Adjusted R-Squared & 0.459218 & S.D dependent var & 20.99190 \\
S.E of Regression & 15.43701 & Akaike info criterion & 8.462424 \\
Sum squared resid & 7149.035 & Schwarz criterion & 8.726344 \\
Log likelihood & -146.3236 & Hannan-Quinn criter & 8.554539 \\
F-Statistic & 6.944207 & Durbin-Watson stat & 0.854970 \\
Prob(F-statistic) & 0.000205 & & \\
\hline
\end{tabular}

Source: Data processed (PLS, 2020).

The multiple regression model formula obtained in this study is:

$$
\begin{aligned}
& \mathrm{FSR}=-276,282-10,836 \mathrm{ROA}+0,121 \mathrm{CAR}+\text { 0,022 Company Size }-0.526 \mathrm{OEOI}+ \\
& 0,055 \mathrm{LDR}+\mathrm{e}
\end{aligned}
$$

The Return on Asst (ROA) variable on the Financial Sustainability Ratio shows that the t-count value is smaller than the t-table (-0.460 smaller than 1.679) with a significance level $(\mathrm{p}$-value $)=0.64(>0.05)$. Because the p-value more than $(5 \%)$ and the coefficient is negative -10.836 , then $\mathrm{H} 1$ is rejected. These results state that the Return on Assets (ROA) has a negative and insignificant effect on the Financial Sustainability Ratio. The variable Capital Adequacy Ratio (CAR) to Financial Sustainability Ratio shows that the t-count value is greater than t-table (2.613 more than 1.679) with a significance level ( $\mathrm{p}$-value $)=$ 0.01 (smaller than 0.05). Because the p-value smaller than $(5 \%)$ and the coefficient are 
positive 0.121, then $\mathrm{H} 2$ is accepted. These results state that the Capital Adequacy Ratio (CAR) has a positive and significant effect on the Financial Sustainability Ratio. Company Size variable on Financial Sustainability Ratio shows that the t-count value is greater than $\mathrm{t}$-table (2.033 more than 1.679) with a significance level (p-value) $=0.05(=0.05)$. Because the $\mathrm{p}$-value $=(5 \%)$ and the coefficient are positive 0.022 , then $\mathrm{H} 3$ is accepted. These results state that the company's size has a positive and significant effect on the Financial Sustainability Ratio. The variable Operating Expenses Operating Income (OEOI) to the Financial Sustainability Ratio shows that the t-count value is greater than $t$-table $(-2.648$ more than 1.679) with a significance level ( $\mathrm{p}$-value $)=0.01$ (smaller than 0.05). Because the p-value smaller than (5\%) and the coefficient are negative 0.526 , then $\mathrm{H} 4$ is accepted. These results state that Operating Expenses Operating Income (OEOI) has a negative and significant effect on the Financial Sustainability Ratio. The Loan To Deposit Ratio (LDR) variable on the Financial Sustainability Ratio shows that the t-count value is greater than the $\mathrm{t}$-table (3.583 more than 1.679) with a significance level ( $\mathrm{p}$-value) $=0.00$ (smaller than $0.05)$. Because the p-value smaller than (5\%) and the coefficient are positive 0.055 , then $\mathrm{H} 4$ is accepted. These results state that the Loan To Deposit Ratio (LDR) positively and significantly affects the Financial Sustainability Ratio.

\section{DISCUSSION}

The results of testing the first hypothesis (H1) found that Return on Assets (ROA) had a negative and insignificant effect on the Financial Sustainability Ratio. These results illustrate that the income earned by the bank does not affect the Financial Sustainability Ratio; if the payment is higher than the costs incurred by the bank, the bank will make a profit. In Islamic banking, the purpose of its activities is not only to want profit but for the common good so that profit is not the only determinant of the company's sustainability in the future. Abnormal profit conditions will allow the profit function to be not optimal. The results of this study contradict agency theory which states that conflicts of interest between managers (agents) and stakeholders (principals) cause agency problems. Manager behavior is not always aimed at stakeholders' interests (principals). However, sometimes managers behave in the manager's interests without paying attention to the impact caused to stakeholders (principals). Imbalance of information or what is known as information asymmetry conditions that spur agency conflicts due to differences in information knowledge from the managers (agents) and stakeholders (principals) so that managers can manipulate financial statement information without the stakeholders (principals) knowing the actual truth. Viewed from the agency theory perspective, shareholders have more attention to the company's sustainability, which Return On Assets (ROA) influences.

The results of this study support the signaling theory, which explains why companies urge to provide financial statement information to external parties. The company suggests providing information because information asymmetry exists between the company and outside parties. After all, the company (manager) knows more about the company and its prospects than outside parties (investors, creditors). Signal theory suggests how a company should give signals to users of financial and non-financial statements (Leonardi et al, 2016). This signal is in the form of information about what management has done to realize the owners, namely maximizing their profits. Signals can be in promotions or other information stating that the company is better than other companies. Financial Sustainability Ratio 
disclosures can be used by management to show shareholders or investors as a signal in the form of good news given by management to the public that the company has good prospects in the future and ensures sustainable development. The results of this study support the research results (Yuliawati et al., 2020), finding that ROA has no significant effect on the Financial Sustainability Ratio (FSR). However, in contrast to (Rianasari \& Pangestuti, 2016; Miranti, 2018; Saputri, 2019) finding that Return On Assets (ROA) has a positive and significant effect on the Financial Sustainability Ratio (FSR).

The results of testing the second hypothesis (H2) found that the Capital Adequacy Ratio (CAR) had a significant positive effect on the Financial Sustainability Ratio. These results illustrate that all Islamic commercial banks listed on the Indonesia Stock Exchange have followed the provisions of Bank Indonesia, namely a minimum CAR value of $8 \%$. It explains that the greater the value of the capital adequacy ratio of a bank, the better the value of the financial sustainability ratio. It is in line with the researcher's hypothesis that the better the flow of capital adequacy ratio, the bank can adequately manage its operational activities and is sustainable. The value of the capital adequacy ratio or capital adequacy serves to accommodate the risk of loss that the bank may face, if a bank has high capital adequacy, the bank's ability to bear the risk of any risky credit or productive assets, besides that the bank can also finance operational activities and make a considerable contribution to the probability of the bank. The results of this study support the agency theory, which states that conflicts of interest between managers (agents) and stakeholders (principals) cause agency problems, managers' behavior is not always aimed at the interests of stakeholders (principals), but sometimes managers behave in the interests of the manager himself without paying attention. Impact on stakeholders (principals). Imbalance of information or what is known as information asymmetry conditions that spur agency conflicts due to differences in information knowledge from the managers (agents) and stakeholders (principals) so that managers can manipulate financial statement information without the stakeholders (principals) knowing the actual truth. Viewed from the perspective of agency theory, shareholders have more attention to the company's sustainability, which is influenced by the Capital Adequacy Ratio (CAR). The results of this study also support the signaling theory, which explains why companies urge to provide financial statement information to external parties. The company suggests providing information because information asymmetry exists between the company and outside parties. After all, the company (manager) knows more about the company and its prospects than outside parties (investors, creditors). Signal theory suggests how a company should give signals to users of financial and non-financial statements (Leonardi et al, 2016). This signal is in the form of information about what management has done to realize the owners, namely maximizing their profits. Signals can be in promotions or other information stating that the company is better than other companies. Financial Sustainability Ratio disclosures can be used by management to show shareholders or investors as a signal in the form of good news given by management to the public that the company has good prospects in the future and ensures sustainable development. The results of this study also support the results of research (Saputri, 2019) finding that the Capital Adequacy Ratio (CAR) has a positive and significant effect on the Financial Sustainability Ratio. It means that the higher the Capital Adequacy Ratio (CAR), the better the Financial Sustainability Ratio (FSR) of the bank concerned. However, in contrast to (Larasati et al., 2019) finding that the Capital Adequacy Ratio (CAR) has no significant effect on the Financial Sustainability Ratio. 
The results of testing the third hypothesis (H3) found that firm size had a significant positive effect on the Financial Sustainability Ratio. It means that large companies generally have large amounts of assets. The size of this company is an indicator that investors can use in determining their investment decisions through the Financial Sustainability Ratio to know the company's sustainability in the future. It will affect the proportion disbursed by banks because banks maintain liquidity and increase bank profits. The results of this study support the agency theory, which states that conflicts of interest between managers (agents) and stakeholders (principals) cause agency problems, managers' behavior is not always aimed at the interests of stakeholders (principals), but sometimes managers behave in the interests of the manager himself without paying attention impact on stakeholders (principals). Imbalance of information or what is known as information asymmetry conditions that spur agency conflicts due to differences in information knowledge from the managers (agents) and stakeholders (principals) so that managers can manipulate financial statement information without the stakeholders (principals) knowing the actual truth. Viewed from the perspective of agency theory, shareholders have more attention to the company's sustainability, which is influenced by the company's size.

The results of this study also support the signaling theory, which explains why companies urge to provide financial statement information to external parties. The company urges to provide information because information asymmetry exists between the company and outside parties. After all, the company (manager) knows more about the company and its prospects than outside parties (investors, creditors). Signal theory suggests how a company should give signals to users of financial and non-financial statements (Leonardi et al, 2016). This signal is in the form of information about what management has done to realize the owners, namely maximizing their profits. Signals can be in promotions or other information stating that the company is better than other companies. Financial Sustainability Ratio disclosures can be used by management to show shareholders or investors as a signal in the form of good news given by management to the public that the company has good prospects in the future and ensures sustainable development. The study results (Saputri, 2019) found that company size had a positive and significant effect on the Financial Sustainability Ratio.

The results of testing the fourth hypothesis (H4) found that Operating Expenses Operating Income (OEOI) had a negative and significant effect on the Financial Sustainability Ratio. It means that the smaller the Operating Expenses Operating Income (OEOI), the greater its sustainable ability. The operating income obtained by Islamic commercial banks increases because one of the components of operating income increases, such as profit-sharing receivables, loans, and financing. Profit-sharing receivables, card loans, and financing are components of financial income. The results of this study support the agency theory, which states that conflicts of interest between managers (agents) and stakeholders (principals) cause agency problems, managers' behavior is not always aimed at the interests of stakeholders (principals), but sometimes managers behave in the interests of the manager himself without paying attention impact on stakeholders (principals). Imbalance of information or what is known as information asymmetry conditions that spur agency conflicts due to differences in information knowledge from the managers (agents) and stakeholders (principals) so that managers can manipulate financial statement information without the stakeholders (principals) knowing the actual truth. Viewed from the 
agency theory perspective, shareholders have more attention to the company's sustainability, which is influenced by Operating Expenses Operating Income (OEOI).

The results of this study also support the signaling theory, which explains why companies urge to provide financial statement information to external parties. The company suggests providing information because information asymmetry exists between the company and outside parties. After all, the company (manager) knows more about the company and its prospects than outside parties (investors, creditors). Signal theory suggests how a company should give signals to users of financial and non-financial statements (Leonardi et al, 2016). This signal is in the form of information about what management has done to realize the owners, namely maximizing their profits. Signals can be in promotions or other information stating that the company is better than other companies. Financial Sustainability Ratio disclosures can be used by management to show shareholders or investors as a signal in the form of good news given by management to the public that the company has good prospects in the future and ensures sustainable development. The results of this study support the research results (Yuliawati et al., 2020), finding that Operating Expenses Operating Income (OEOI) has a negative and significant effect on the Financial Sustainability Ratio. However, in contrast to the results found by (Saputri, 2019) and (Abbas et al., 2020), they found that Operating Expenses Operating Income (OEOI) did not affect the Financial Sustainability Ratio.

The results of testing the fifth hypothesis (H5) found that it had a positive and significant effect on the Financial Sustainability Ratio. That is when associated with interest income and interest costs. A high LDR indicates that the amount of credit disbursed is higher than TPF. The bank will earn interest income from loans disbursed, and a low amount of TPF will benefit the bank in terms of interest costs that must be spent on customer deposits. An increase in interest income and a decrease in interest costs will increase the Financial Sustainability Ratio (FSR). The results of this study support the agency theory, which states that conflicts of interest between managers (agents) and stakeholders (principals) cause agency problems, managers' behavior is not always aimed at the interests of stakeholders (principals), but sometimes managers behave in the interests of the manager himself without paying attention impact on stakeholders (principals). Imbalance of information or what is known as information asymmetry conditions that spur agency conflicts due to differences in information knowledge from the managers (agents) and stakeholders (principals) so that managers can manipulate financial statement information without the stakeholders (principals) knowing the actual truth. Viewed from the agency theory perspective, shareholders have more attention to the company's sustainability, which is influenced by the Loan to Deposit Ratio (LDR).

The results of this study also support the signaling theory, which explains why companies urge to provide financial statement information to external parties. The company suggests providing information because information asymmetry exists between the company and outside parties. After all, the company (manager) knows more about the company and its prospects than outside parties (investors, creditors). Signal theory suggests how a company should give signals to users of financial and non-financial statements (Leonardi et al, 2016). This signal is in the form of information about what management has done to realize the owners, namely maximizing their profits. Signals can be in promotions or other information stating that the company is better than other companies. Financial Sustainability Ratio disclosures can be used by management to show shareholders or 
investors as a signal in the form of good news given by management to the public that the company has good prospects in the future and ensures sustainable development. The results of this study also support the results of research (Santoso et al., 2017; Sahetapy, 2019), finding that the Loan to Deposit Ratio (LDR) has a positive and significant effect on the Financial Sustainability Ratio (FSR).

\section{CONCLUSION}

Based on the results of hypothesis testing in this study, the following conclusions were obtained: First, Return on Assets (ROA) has a negative and insignificant effect on the Financial Sustainability Ratio. It means that every increase in Return On Assets (ROA) does not affect the increase in the Financial Sustainability Ratio at Islamic commercial banks in Indonesia. Second, the capital adequacy ratio (CAR) has a positive and significant effect on the size of the financial sustainability ratio. It means that every increase in the capital adequacy ratio (CAR) causes an increase in the value of the financial sustainability ratio in Islamic commercial banks in Indonesia. Third, the company's size has a positive and significant effect on the size of the financial sustainability ratio. It means that every increase in company size causes an increase in the value of the financial sustainability ratio in Islamic commercial banks in Indonesia. Fourth, Operating Expenses Operating Income (OEOI) has a negative and significant effect on the financial sustainability ratio of Islamic retail banks in Indonesia. It means that an increase or decrease in OEOI will affect the rise and fall of the FSR in Islamic commercial banks in Indonesia. Fifth, the Loan To Deposit Ratio (LDR) positively and significantly affects the financial sustainability ratio. The increase or decrease in FDR in this study affects the rise and fall of the FSR value in Islamic commercial banks in Indonesia.

\section{REFERENCES}

Abbas, D. S., Eksandy, A., dan Yuniarti, Y. (2020). Sustainabillity Ratio pada Bank Umum Syariah di Indonesia Beserta Faktor yang Mempengaruhinya. JES (Jurnal Ekonomi Syariah), 5(2).

Aprilliadi, T. (2020). Pengaruh Rasio Capital Adequacy Ratio (Car), Non Performing Loan (Npl) Dan Loans To Deposit Ratio (Ldr) Terhadap Prediksi Kondisi Bermasalah Pada Sektor Perbankan. Jurnal Revenue: Jurnal Ilmiah Ilmu Akuntansi, 1(1), 68-80.

Ahmad, H., Mappatompo, A., and Muslim, M. (2018). Capital Ownership Structure And Decision On Fi-financial Market Reaction And Corporate Value. International Journal of Innovative Science and Re-search Technology, 3(9), 395-406.

Armereo, C. (2015). Analisis Faktor-Faktor yang Mempengaruhi Profitabilitas Bank Syariah yang Terdaftar di Bursa Efek Indonesia Indonesia. Jurnal Ilmiah Ekonomi Global Masa Kini, 6(2), 48-56.

Arsyad, M., Haeruddin, S. H., Muslim, M., and Pelu, M. F. A. (2021). The effect of activity ratios, liquidity, and profitability on the dividend payout ratio. Indonesia Accounting Journal, 3(1), 36-44.

Astuti, A. R. T., Pagalung, G., dan Kara, M. H. (2022). Rasio Kecukupan Modal Bank Syariah: Antara Mitigasi Dan Efisiensi. Jurnal Ilmiah MEA (Manajemen, Ekonomi, \& Akuntansi), 6(1), 147-156. 
Basse, Ii. P., dan Mulazid, A. S. (2017). Analisa Pengaruh Kualitas Aset, Likuiditas, Efensiensi Usaha Dan Profitabilitas Terhadap Rasio Kecukupan Modal Pada Umum Syariah Periode 2012-2015. Al-Tijary, 109-123.

Diana, S., Sulastiningsih, S., dan Purwati, P. (2021). Analisis Kinerja Keuangan Perbankan Syariah Indonesia Pada Masa Pandemi Covid-19. Jurnal Riset Akuntansi Dan Bisnis Indonesia, 1(1), 111-125.

Edo, D. S. R., dan Wiagustini, N. L. P. (2014). Pengaruh dana pihak ketiga, non performing loan, dan capital adequacy ratio terhadap loan to deposit ratio dan return on assets pada sektor perbankan di Bursa Efek Indonesia. E-Jurnal Ekonomi Dan Bisnis Universitas Udayana, 3(11), 650-673.

Harianto, S. (2017). Rasio Keuangan dan Pengaruhnya Terhadap Profitabilitas Pada Bank Pembiayaan Rakyat Syariah. Esensi: Jurnal Bisnis Dan Manajemen, 7(1), 41-48.

Hartanto, D., Nurlaela, S., dan Titisari, K. H. (2020). Financing Deposit Ratio, Badan Operasional Pendapatan Operasional, Non Performing Financing Dan Profitabilitas Perusahaan Perbankan Syariah Di Indonesia. Jurnal Akuntansi Dan Keuangan, 11(2), 45-57.

Hermuningsih, S. (2012). Pengaruh profitabilitas, size terhadap nilai perusahaan dengan sruktur modal sebagai variabel intervening. Jurnal Siasat Bisnis, 16(2).

Ismanto, D., dan Laksono, D. K. A. (2020). Analisis Perbandingan Kinerja Keuangan pada Bank Umum Syariah BUMN (Bank BRI Syariah, Bank Syariah Mandiri dan Bank BNI Syariah). Jurnal Pasar Modal Dan Bisnis, 2(2), 99-114.

Kurniawan, A. T., dan Suwarti, T. (2017). Pengaruh Profitabilitas, Leverage, Likuiditas Dan Produktifitas Terhadap Peringkat Obligasi. Seminar Nasional Multi Disiplin Ilmu Unisbank 2017.

Larasati, D. G., Isynuwardhana, D., dan Asalam, A. G. (2019). Corporate Governance, Rasio-Rasio Keuangan Dan Financial Sustainability Pada Perbankan Umum Di Indonesia (Studi Pada Perusahaan Perbankan yang Terdaftar di Bursa Efek Indonesia periode 2014-2017). ISEI Accounting Review, 3(2), 39-43.

Miranti, T. (2018). Faktor Rasio Keuangan terhadap Sustainability Perbankan di Indonesia: Menggunakan Regresi Logistik. Jurnal Ekonomi Akuntansi Dan Manajemen, 17(2), 107.

Mulazid, A. S. (2017). Analisa Pengaruh Size Perusahaan, Capital Adequacy Ratio (CAR), Non Perfoming Financing (NPF), Return On Asset (ROA), Financing Deposit Ratio (FDR) Terhadap Pengungkapan Corporate Social Responsibility (CSR) Bank Umum Syariah di Indonesia Periode 2012-201. HUMAN FALAH: Jurnal Ekonomi Dan Bisnis Islam, 4(1).

Mustari, G. A., Iyan, E., dan Sixpria, N. (2020). Pengaruh Financing To Deposit Ratio (Fdr), Non Performing Financing (Npf) Dan Biaya Operasional Pendapatan Operasional (Bopo) Terhadap Profitabilitas Pada BRI Syariah Periode 2011-2018. ACCOUNT: Jurnal Akuntansi Keuangan Dan Perbankan, 7(1).

Nuryanto, U. W., Salam, A. F., Sari, R. P., dan Suleman, D. (2020). Pengaruh Rasio Kecukupan Modal, Likuiditas, Risiko Kredit Dan Efisiensi Biaya Terhadap Profitabilitas Pada Bank Go Public. Jurnal Akuntansi Dan Keuangan, 7(1), 1-9.

Prasetyo, D. A., dan Darmayanti, N. P. A. (2015). Pengaruh Risiko Kredit, Likuiditas, Kecukupan Modal, Dan Efisiensi Operasional Terhadap Profitabilitas Pada PT BPD Bali. E-Jurnal Manajemen Unud, 4(9), 2590-2617. 
Pristianingrum, N. (2017). Peningkatan efisiensi dan produktivitas perusahaan manufaktur dengan sistem Just In Time. ASSETS: Jurnal Ilmiah Ilmu Akuntansi, Keuangan Dan Pajak, 1(1), 41-53.

Priyadi, M. P. (2018). Pengaruh profitabilitas dan size terhadap nilai perusahaan dengan CSR sebagai variabel pemoderasi. Jurnal Ilmu Dan Riset Akuntansi (JIRA), 7(3).

Puspitasari, F., dan Ernawati, E. (2010). Pengaruh mekanisme corporate governance terhadap kinerja keuangan badan usaha. Jurnal Manajemen Teori Dan Terapan, 3(2).

Putri, C. E., Jonathan, R., dan Lau, E. A. (2018). Analisis Kinerja Keuangan Bank Mandiri Konvensional Dan Bank Mandiri Syariah Cabang Sangatta. Ekonomia, 7(2), 108-123.

Putri, N. P. S. W., dan Dana, I. M. (2018). Pengaruh NPL, likuiditas, dan rentabilitas terhadap CAR pada BPR konvensional skala nasional di Indonesia. E-Jurnal Manajemen Unud, 7(4), 1862-1891.

Rahayu, R., dan Cahyati, A. D. (2015). Komparasi asimetri informasi sebelum dan sesudah konvergensi IFRS (studi kasus pada perusahaan agriculture dan mining yang terdaftar di BEI). Widya Warta: Jurnal Ilmiah Universitas Katolik Widya Mandala Madiun, 39(01), 25-40.

Raranta, N. G., Nangoi, G. B., dan Pangerapan, S. (2021). Analisis Kinerja Keuangan Hotel Berdasarkan Rasio Profitabilitas Pada Hash Inn Marina Manado. Jurnal EMBA: Jurnal Riset Ekonomi, Manajemen, Bisnis Dan Akuntansi, 9(2).

Ratih, I., dan Damayanthi, I. (2016). Kepemilikan Manajerial Dan Profitabilitas Pada Nilai Perusahaan Dengan Pengungkapan Tanggungjawab Sosial Sebagai Variabel Pemoderasi. E-Jurnal Akuntansi Universitas Udayana, 14(2), 1510-1538.

Rianasari, S., dan Pangestuti, I. R. D. (2016). Analisis Rasio Kinerja Keuangan Terhadap Financial Sustainability Bank Perkreditan Rakyat (Bpr) Di Jawa Tengah (Periode 2010-2014). Diponegoro Journal of Management, 5(2), 575-589.

Sahetapy, K. A. (2019). The Relationship Between Macroeconomy Factors and Indonesian Banks' Financial Sustainability. Abstract Proceedings International Scholars Conference, 7(1), 1204-1216.

Santoso, J., Khairunnisa, K., dan Triyanto, D. N. (2017). Pengaruh Capital Adequacy Ratio, Non Performing Loan Dan Loan To Deposit Ratio Terhadap Financial Sustainability Ratio (Studi Empiris Pada Bank Umum Swasta dan Nasional yang terdaftar di Bursa Efek Indonesia Periode 2011-2015). Competitive Jurnal Akuntansi Dan Keuangan, $1(2)$.

Saputri, K. O. (2019). Kinerja keuangan terhadap kemampuan berkelanjutan perusahaan. Jurnal Riset Akuntansi Kontemporer, 11(1), 24-32.

Sarwono, A. E., dan Sunarko, M. R. (2016). Pengaruh Variabel Rasio Keuangan Terhadap Financial Sustainability Ratio Pada Bank Campuran Periode 20011-2013. Eksplorasi, 27(2).

Supeno, W. (2017). Analisis Kinerja Penghimpunan Dana dalam Meningkatkan Penyaluran Kredit pada Bank Perkreditan Rakyat. Moneter-Jurnal Akuntansi Dan Keuangan, 4(2), 121-131.

Syakhrun, M., Anwar, A., dan Amin, A. (2019). Pengaruh Car, Bopo, Npf Dan Fdr Terhadap Profitabilitas Pada Bank Umum Syariah Di Indonesia. Bongaya Journal for Research in Management (BJRM), 2(1), 1-10. 
Wicaksono, A., dan Hasthoro, H. A. (2014). Pengaruh Asimetri Informasi Terhadap Praktik Manajemen Laba (Studi Pada Perusahaan LQ-45 Yang Terdaftar Di Bursa Efek Indonesia). Jurnal Bisnis Dan Ekonomi, 5(1), 31-47.

Wijayanti, R. (2016). Pengaruh pengungkapan sustainability report terhadap kinerja keuangan perusahaan. Syariah Paper Accounting FEB UMS, 6, 39-51.

Yuliawati, Y., Jensen, L., dan Saputri, P. S. (2020). Analisis Faktor-Faktor Yang Mempengaruhi Financial Sustainability Ratio Perbankan Syariah Diindonesia Periode 2010-2016. AL-IQTISHADY: Jurnal Ekonomi Syariah, 1(2), 132-140.

Zebua, Y. (2014). Analisis Likuiditas Bank Mandiri Tahun 2009-2013. ECOBISMA (Jurnal Ekonomi, Bisnis Dan Manajemen), 1(2), 19-25 